\title{
Peran anggota keluarga pada usaha pemeliharaan ternak sapi potong di Kelurahan Makalonsouw Kecamatan Tondano Timur
}

\author{
S. Takasenserang, S.O.B. Lombogia *, J.A. Malingkas, A.A. Sajow \\ Fakultas Peternakan Universitas Sam Ratulangi Manado 95115 \\ *Korespondensi (corresponding author): lombogiastanly@yahoo.co.id
}

\begin{abstract}
ABSTRAK
Penelitian ini bertujuan untuk mengetahui peran anggota keluarga pada usaha pemeliharaan ternak sapi potong, serta peran anggota keluarga terhadap akses informasi, aspek kelembagaan, aspek kontrol, aspek pengambilan keputusan, dan aspek manfaat. Penelitian ini dilaksanakan di Kelurahan Makalonsow Kecamatan Tondano Timur pada bulan September - Oktober 2019. Jenis penelitian survei dengan mengunakan metode kualitatif. Pengumpulan data melalui wawancara dengan menggunakan koesioner kepada anggota keluarga peternak. Pemilihan sampel responden ditentukan secara sengaja purposive, dan pengukuran variabel dilakukan dengan menggunakan alat ukur Skala Guttman, pengukurannya diberi skor pada setiap jawaban. Hasil penelitian menunjukan peran keluarga terhadap akses informasi dari kegiatan penyuluhan yakni peran suami $100 \%$, peran istri $0 \%$, akses lembaga dalam penyuluhan di Kelurahan Makalonsow Tondano Timur, peran suami $100 \%$, istri $0 \%$, aspek kontrol dalam pemeliharaan sapi potong yakni pada kegiatan membersihkan kandang, suami $100 \%$, kegiatan memandikan ternak, suami 96,67\% anak $3,33 \%$, kegiatan memberi pakan dan minum pada sapi potong, suami $60 \%$ istri $26,67 \%$ dan anak $13,33 \%$, aspek pengambilan keputusan peternak dalam kegiatan pembelian bibit, suami $100 \%$, penjualan ternak, suami $93,33 \%$ istri $6,67 \%$, pembelian ternak suami $100 \%$. Berdasarkan hasil penelitian, menunjukan kepala keluarga berperan penting terhadap usaha pemeliharaan ternak sapi potong di Kelurahan Makalonsow Kecamatan Tondano Timur.
\end{abstract}

Kata Kunci : Peran anggota keluarga, sapi potong.

\begin{abstract}
THE ROLE OF FAMILY MEMBERS IN CATTLE RAISING IN MAKALONSOUW VILLAGE EAST TONDANO DISTRICT This study aims to find out the role of family members in the business of keeping beef cattle, as well as the role of family members to access information, institutional aspects of control aspects, aspects of decision making, and aspects of benefits. This research was conducted in Makalonsow Subdistrict, East Tondano in September - October 2019. Types of survey research using qualitative methods. Data collection through interviews using a coesioner to family members of breeders. The selection of sample respondents was determined deliberately purposive, and variable measurement was carried out using the Guttman Scale measuring instrument, the measurement is scored on each answer. The results showed the role of the family to access information from counseling activities, namely the role of husband $100 \%$, the role of wife $0 \%$, access institutions in counseling in the Village Makalonsow Tondano Timur, the role of husband $100 \%$, wife $0 \%$, aspects of control in the maintenance of beef cattle, namely in the activities of cleaning cages, husband $100 \%$, bathing activities of cattle, husband $96.67 \%$ children $3.33 \%$, activities of feeding and drinking to beef cattle, husband $60 \%$ wife $26.67 \%$ and children $13.33 \%$, aspects
\end{abstract}


of farmer decision making in seed purchasing activities, husband $100 \%$, livestock sales, husband $93.33 \%$ wife $6.67 \%$, husband's livestock purchase $100 \%$. Based on the results of the study, showed the head of the family played an important role in the business of keeping beef cattle in Makalonsow Village, East Tondano District.

Keywords: The role of family members, cattle.

\section{PENDAHULUAN}

Sektor peternakan di Indonesia telah memberikan peran yang cukup besar dalam perekonomian secara keseluruhan. Permintaan akan produk peternakan meningkat dari tahun ketahun sejalan dengan kebutuhan gizi masyarakat. Pangan berupa produk peternakan adalah daging, susu dan telur yang sangat diperlukan untuk meningkatkan kualitas sumberdaya manusia (Susanti, 2015). Pengembangan peternakan pada saat ini, menunjukan prospek yang sangat cerah dan mempunyai peranan yang sangat penting dalam pertumbuhan ekonomi pertanian Indonesia (Purtanto, 2016).

Sapi potong merupakan salah satu sumber daya penghasil daging yang memiliki nilai ekonomi tinggi, dan penting artinya di dalam kehidupan masyarakat. Daging sapi sangat besar manfaatnya bagi pemenuhan gizi berupa protein hewani. Ternak sapi sebagai salah satu hewan pemakan rumput sangat berperan sebagai pengumpul, bahan bergizi rendah yang di ubah menjadi bahan bergizi tinggi kemudian di teruskan kepada manusia dalam bentuk daging (Siregar, 2009).

Peternakan adalah proses membudidayakan hewan ternak untuk mendapatkan manfaat dan hasil dari kegiatan tersebut. Peternak pada umumnya dalam mengelola usaha ternaknya berperan sebagai tenaga kerja. Tenaga kerja keluarga nilainya tidak bisa diabaikan begitu saja, karena tenaga kerja merupakan salah satu komponen produksi dalam pemeliharaan ternak sapi potong (Darmawi, 2012).

Tenaga kerja yang digunakan dalam usaha pemeliharaan ternak sapi potong biasanya berasal dari dalam keluarga, yang terdiri dari tenaga kerja suami, tenaga kerja istri dan tenaga kerja anak-anak. Peternak jarang menggunakan tenaga kerja upahan dalam mengelola usahanya, karena biaya yang dikeluarkan akan bertambah. Partisipasi anggota keluarga dalam usaha pemeliharaan ternak sapi potong terdiri dari mencari hijauan, menggembala, membersihkan kandang, memberikan pakan dan minum (Utari, 2017).

Dalam usaha pemeliharaan ternak sapi potong keterlibatan keluarga dalam mengelola usaha ternak sapi potong seperti, kepala rumah tangga dan juga anggota keluarga ikut serta dalam membantu pemeliharaan ternak sapi seperti, istri dan anak. Peranan ini terlihat dari komponen dalam peran tenaga kerja keluarga, pada usaha sapi potong seperti peran anggota keluarga terhadap aspek akses, aspek kontrol, aspek pengambilan keputusan dan aspek manfaat.

Kelurahan Makalonsow Kecamatan Tondano Timur, merupakan salah satu kelurahan yang potensial untuk usaha ternak sapi potong. Usaha sapi potong di Kelurahan Makalonsow masih dalam skala rumah tangga, yang rata-rata kepemilikan ternak sapi potong yaitu 2-8 ekor. Masyarakat berpendapat, bahwa dalam usaha pemeliharaan sapi potong memerlukan biaya yang cukup besar. Dilihat dari segi tenaga kerja, usaha ternak sapi potong di Kelurahan Makalonsow hanya melibatkan anggota keluarga dalam mengelolah usahanya. Namun dalam pemeliharaan usaha sapi potong, tenaga kerja yang paling berperan hanya kepala rumah tangga (suami), sedangkan istri dan anaknya masih kurang berperan dalam usaha pemeliharaan sapi potong.Peran anggota keluarga diperlukan karena dalam 
sektor peternakan, skala rumah tangga sangat membutuhkan tenaga kerja, seperti kepala rumah tangga, istri dan anak untuk mengelola usaha peternakan sapi potong. Untuk melihat kesetaraan peran keluarga dalam usaha sapi potong dapat dilihat dari beberapa aspek yaitu aspek akses, aspek kontrol, aspek pengambilan keputusan dan aspek manfaat. Karena itu penelitian ini bertujuan untuk mengetahui peran anggota keluarga di lihat dari berbagai aspek tersebut dalam pemeliharaan ternak sapi potong.

\section{METODE PENELITIAN}

\section{Lokasi dan waktu penelitian}

Penelitian ini telah dilaksanakan di

Kelurahan Makalonsow, Kecamatan Tondano Timur selama satu bulan dari September 2019 - Oktober 2019.

\section{Jenis penelitian}

Penelitian ini berbentuk survey, dimana hal ini dimaksudkan sebagai suatu penelitian dengan cara menghimpun informasi dari sampel yang diperoleh dari suatu populasi, dengan tujuan untuk melakukan generalisasi sejauh populasi dari mana sampel tersebut diambil (Paturochman, 2012). Jenis penelitian secara deskriptif kualitatif yaitu penelitian yang bersifat menjelaskan bagaimana peran anggota keluarga terhadap proses usaha pemeliharaan ternak sapi di Kelurahan Makalonsow, Kecamatan Tondano Timur.

\section{Populasi dan sampel penelitian}

1. Populasi dalam penelitian ini adalah keseluruan anggota rumah tangga peternak sapi potong yaitu berjumlah 30 orang, yang berada di Kelurahan Makalonsouw, Kecamatan Tondano Timur.

2. Sampel lokasi penelitian, ditentukan secara sengaja purposive, yaitu merupakan suatu metode yang berdasarkan atas pertimbanganpertimbangan tertentu Rintjap et al.
(2018). Dasar pertimbangan yang dipakai dalam memilih sampel ialah kelurahan yang memiliki populasi ternak sapi yang cukup besar. Sedangkan untuk pemilihan responden diambil seluruh peternak sapi potong yang berada di Kelurahan Makalonsouw, Kecamatan Tondano Timur, berjumlah 30 orang.

\section{Sumber data}

Sumber data yang digunakan dalam penelitian ini adalah data primer dan data sekunder.

1. Data primer yaitu data yang diperoleh dari hasil observasi wawancara langsung, dan melalui bantuan daftar kuesioner kepada peternak sapi yang ada di Kecamatan Tondano Timur, Kelurahan Makalonsouw.

2. Data sekunder adalah data yang diperoleh dari Dinas Peternakan, yaitu populasi ternak dan jumlah peternakan yang ada di Kecamatan Tondano Timur, Kelurahan Makalonsouw.

\section{Analisis data}

Analisis data yang akan digunakan dalam penelitian ini adalah analisis deskriptif, yaitu suatu metode atau cara untuk menganalisis dan menguraikan data penelitian yang ada, dan dikaitkan dengan teori-teori yang ada.

Analisa data yang digunakan untuk mengetahui peran keluarga adalah dengan menggunakan statistik desktiptif yaitu menggambarkan variabel demi variabel, satu demi satu data yang pada umumnya berbentuk uraian atau kalimat yang merupakan informasi mengenai keadaan sebagaimana adanya sumber data, dalam hubungannnya dengan masalah yang diteliti (Solikhah, 2016). Dalam penelitian ini yakni dari segi aspek akses, aspek kontrol, aspek pengambilan keputusan, dan aspek manfaat pada peran tenaga kerja keluarga pada usaha ternak sapi potong. Selanjutnya untuk mengukur segi aspek tersebut maka menggunakan alat ukur skala Guttman. 
Menurut Siregar (2011), skala pengukuran skala Guttman akan didapat jawaban yang tegas, yaitu ya atau tidak, benar atau salah, pernah atau tidak, positif atau negatif dan lain-lain. Jawaban ya diberi skor 1 dan untuk jawaban tidak diberi skor 0 .

\section{HASIL DAN PEMBAHASAN}

\section{Keadaan geografis}

Berdasarkan posisi geografisnya, Kecamatan Tondano Timur memiliki batas-batas: Utara-Kecamatan Tondano Utara; Selatan-Kecamatan Eris; BaratKecamatan Tondano Barat; Timurkecamatan Kombi. Kecamatan Tondano Timur Terdiri dari 11 kelurahan, yaitu: Toulour, Kiniar, Taler, Liningaan, Katinggolan, Kendis, Wengkol, Ranowangko, Luaan, Papakelan, Makalonsow.

\section{Umur responden}

Umur merupakan salah satu faktor yang mempengaruhi perilaku dalam melakukan atau mengambil keputusan dan dapat bekerja secara optimal serta produktif. Kegiatan bekerja sangat dipengaruhi oleh umur bagi masyarakat pedesaan, hal ini dikarenakan pekerjaan mereka menuntut tenaga yang kuat seperti jika bekerja pada bidang pertanian dan peternakan, BPS Kabupaten Minahasa (2019). Berdasarkan komposisi penduduk, usia penduduk dikelompokkan menjadi 3 kategori yaitu sebagai berikut:

a. Usia $=14$ tahun: usia muda/usia belum produktif

b. Usia $=15-64$ tahun: usia dewasa/usia kerja / usia produktif

c. Usia $=65$ tahun: usia tua/usia tidak produktif/usia jompo.

Klasifikasi responden berdasarkan umur di Kelurahan Makalonsouw Kecamatan Tondano Timur pada Tabel 1.

Berdasarkan data pada Tabel 1, terlihat bahwa sebagian besar umur responden tergolong pada kategori produktif, dengan rentan umur $20-55$ tahun sebanyak 28 orang $(93,33 \%)$. Sedangkan selebihnya berada pada kategori usia tua atau tidak produktif sebanyak 2 orang (6\%). Hal ini sesuai dengan pendapat Ananta (2015), yang menyatakan bahwa, umur produktif tenaga kerja adalah pada rentang umur 15-55 tahun.

\section{Tingkat pendidikan responden}

Tingkat pendidikan sangat menentukan seseorang dalam bersikap dan mengambil keputusan. Semakin tinggi tingkat pendidikan seseorang maka dapat mempengaruhi cara seseorang dalam menentukan suatu sikap yang rasional. Pendidikan merupakan hal yang sangat penting dalam meningkatkan keterampilan diri khususnya tentang cara beternak dengan baik, Tumober et al. (2014). Dengan latar belakang pendidikan seseorang dianggap mampu melaksanakan suatu pekerjaan tertentu atau tanggung jawab yang diberikan kepadanya. Tingkat pendidikan yang memadai tentunya akanberdampak pada kemampuan manajemen usaha peternakan yang digeluti. Klasifikasi responden berdasarkan umur di Kelurahan Makalonsouw Kecamatan Tondano Timur pada Tabel 2.

Berdasarkan data pada Tabel 2, menunjukkan bahwa tingkat pendidikan masyarakat di Kelurahan Makalonsouw masih tergolong rendah. Hal ini dibuktikan dengan responden dengan tingkat pendidikan rendah yakni SD dan SMP mendominasi tingkat pendidikan yang masing-masing sebesar 36,6\% dan 30\%. Selebihnya pada tingkat pendidikan tinggi yakni SMA sebesar 33,33\%, Jadi disimpulkan bahwa tingkat pendidikan responden masih tergolong rendah. Nurdiyansah et al. (2020), apabila pendidikan rendah maka daya pikirnya sempit maka kemampuan menalarkan suatu inovasi baru akan terbatas, sehingga wawasan untuk maju lebih rendah dibanding dengan peternak yang berpendidikan tinggi. 
Tabel 1. Klarifikasi Responden Berdasarkan Tingkat Umur di Kelurahan Makalonsouw Kecamatan Tondano Timur.

\begin{tabular}{lccc}
\hline No & Klarifikasi Umur (Tahun) & Responden (Orang) & Presentase (\%) \\
\hline 1 & $20-55$ & 28 & 93,33 \\
2 & $>55$ & 2 & 6,67 \\
\hline & Jumlah & 30 & 100 \\
\hline
\end{tabular}

Tabel 2. Klarifikasi Responden Berdasarkan Tingkat Pendidikan Di Kelurahan Makalonsouw Kecamatan Tondano Timur.

\begin{tabular}{lccc}
\hline No & Tingkat Pendidikan & Responden (Orang) & Presentase (\%) \\
\hline 1 & SMA & 10 & 33,33 \\
2 & SMP & 9 & 30 \\
3 & SD & 11 & 36,6 \\
4 & D3 & - & - \\
5 & S1 & - & - \\
\hline & Jumlah & 30 & 100 \\
\hline
\end{tabular}

\section{Peran keluarga terhadap akses informasi}

Peran keluarga terhadap akses informasi di Kelurahan Makalonsow Kecamatan Tondano Timur, para peternak yang melakukan usaha sapi potong tidak mempunyai akses yang sama terhadap informasi karena lebih banyaknya kesempatan yang diperoleh para suami dibandingkan istri dan anak dalam memperoleh informasi. Adapun peran keluarga terhadap akses informasi dapat dilihat pada Tabel 3.

Berdasarkan data pada Tabel 3, menunjukkan bahwa peran keluarga terhadap akses informasi dari kegiatan penyuluhan yakni peran suami sebanyak 30 orang $(100 \%)$, peran istri tidak ada $(0 \%)$, hal ini menunjukkan bahwa suami yang paling dominan dalam mendapatkan informasi dari penyuluh dibandingkan istri dan anaknya, hal ini disebabkan karena suami yang terlibat langsung dalam kelompok tani sehingga suami yang sering mendapatkan informasi dari media penyuluh mengenai usaha tani/ternaknya, sedangkan istri kurang berperan dalam mendapatkan informasi karena pekerjaan pokok istri sebagai ibu rumah tangga yang mengurus dan mengatur seluruh kegiatan rumah tangga. Hal ini sesuai pendapat (Sari et al, 2009), menyatakan bahwa peran istri secara individual dalam akses terhadap sumber daya sangat kecil.

Berdasarkan data pada Tabel 3, menunjukkan bahwa akses informasi yang didapatkan suami, istri dan anak dari surat kabar masih sangat kurang karena kurangnya informasi mengenai peternakan dan pertanian dalam surat kabar. Dalam akses informasi yang didapatkan dari media elektronik, yakni peran suami sebanyak 16 orang $(53,33 \%)$, peran istri sebanyak 14 orang $(46,67 \%)$, hal ini menunjukkan bahwa suami yang paling dominan dalam mendapatkan informasi dari media elektronik dibandingkan istri dan anaknya, hal ini disebabkan karena suami yang terlibat langsung dalam kelompok tani sehingga suami lebih ingin mendapatkan informasi dari media elektronik mengenai peternakan dan pertanian. Tetapi peternak di Kelurahan Makalonsow berpendapat bahwa informasi yang paling banyak yang didaptkan hanya dari penyuluh.

\section{Peran keluarga terhadap akses kelembagaan \\ Peran keluarga terhadap akses}


Tabel 3. Peran Keluarga Terhadap Akses Infromasi Di Kelurahan Makalonsow Kecamatan Tondano Timur.

\begin{tabular}{cccccccc}
\hline No & Kegiatan & Suami & Istri & Jumlah & Suami \% & Istri \% & Jumlah \% \\
\hline 1 & Penyuluhan & 30 & 0 & 30 & 100 & - & 100 \\
2 & Surat Kabar & 28 & 2 & 30 & 93,33 & 6,67 & 100 \\
3 & Media elektronik & 16 & 14 & 30 & 53,33 & 46,67 & 100 \\
\hline
\end{tabular}

Tabel 4. Peran Keluarga Terhadap Akses Kelembagaan Di Kelurahan Makalonsow Kecamatan Tondano Timur.

\begin{tabular}{clcccccc}
\hline No & Kegiatan & Suami & Istri & Jumlah & Suami $\%$ & Istri \% & Jumlah \% \\
\hline 1 & Penyuluhan & 30 & 0 & 30 & 100 & - & 100 \\
2 & Kelompok Tani & 29 & 1 & 30 & 96,67 & 3,33 & 100 \\
3 & Pemasaran & 18 & 12 & 30 & 60 & 40 & 100 \\
\hline
\end{tabular}

kelembagaan di Kelurahan Makalonsow Kecamatan Tondano Timur dapat dilihat pada Tabel 4. Peran keluarga terhadap akses kelembagaan terdiri dari lembaga penyuluhan, kelompok tani, dan lembaga pemasaran, para peternak mengikuti kegiatan penyuluhan dan kelompok tani untuk memperoleh informasi yang diperlukan.

Berdasarkan hasil penelitian pada tabel 4, peran keluarga terhadap akses lembaga dalam penyuluhan di Kelurahan Makalonsow Tondano Timur, peran suami $100 \%$, sedangkan istri tidak ada (0\%). Hal ini menunjukkan bahwa akses lembaga dalam penyuluhan suami lebih berperan dibandingkan istri dan anak. Hal ini sesuai dengan pendapat Santoso dan Kususiyah (2013) menyatakan bahwa dalam kegiatan penyuluhan dominasi pria.

\section{Peran keluarga terhadap aspek kontrol}

Peran keluarga terhadap aspek kontrol yaitu dimana dalam kontrol suatu pembagian tenaga kerja dalam usaha sapi potong melibatkan istri dan anak sebagai tenaga kerja keluarga. Adapun hasil yang diperoleh dalam aspek kontrol dalam pemeliharaan pada usaha sapi potong di Kelurahan Makalonsow Kecamatan Tondano Timur, dapat dilihat pada Tabel 5. :
Tabel 5, menjelaskan bahwa peran keluarga sebagai aspek kontrol dalam pemeliharaan sapi potong yakni pada K1 (membersihkan kandang), K2 (memandikan ternak) dan K3 (memberi pakan dan minum pada sapi potong) didominasi oleh suami, sedangkan K4 (mengelola feses menjadi biogas) tidak ada yang pernah melakukan baik itu suami, istri maupun anak. Dari ketiga jenis kegiatan dalam aspek kontrol dapat diketahui bahwa suami mendominasi kegiatan dalam usaha sapi potong yang dilakukan dilihat dari segi tingginya partisipasi fisiknya, sedangkan istri dan anak masih kurang berperan dalam mengontrol usaha sapi potongnya, ini disebabkan karena curahan waktu kerja yang berbeda-beda.

\section{Peran keluarga terhadap aspek pengambilan keputusan}

Peran keluarga terhadap aspek pengambilan keputusan yang berkaitan dengan kegiatan non-fisik kegiatan usaha ternak keluarga menunjukkan perbedaan. Setiap kegiatan dalam pengambilan keputusan lebih dominan suami dibandingkan istri.Adapun aspek pengambilan keputusan dalam usaha sapi potong yang dilakukan dapat dilihat pada Tabel 6. 
Tabel 5. Peran Keluarga Terhadap Aspek Kontrol Dalam Pemeliharaan Sapi Potong Di Kelurahan Makalonsow Kecamatan Tondano Timur.

\begin{tabular}{cccccccccc}
\hline No & \multicolumn{4}{c}{ Jenis Kegiatan } & \multicolumn{5}{c}{ Presentase \% } \\
\hline & Keluarga & K1 & K2 & K3 & K4 & K1 & K2 & K3 & K4 \\
\hline 1 & Suami & 30 & 29 & 18 & - & 100 & 96,67 & 60 & - \\
2 & Istri & - & - & 8 & - & - & - & 26,67 & - \\
3 & Anak & - & 1 & 4 & - & - & 3,33 & 13,33 & - \\
\hline & Jumlah & 30 & 30 & 30 & 0 & 100 & 100 & 100 & - \\
\hline
\end{tabular}

Tabel 6. Peran Keluarga Terhadap Aspek Pengambilan Keputusan Di Kelurahan Makalonsow Kecamatan Tondano Timur.

\begin{tabular}{llcccccc}
\hline No & & \multicolumn{3}{c}{ Jenis Kegiatan } & \multicolumn{3}{c}{ Presentase \% } \\
\hline & Keluarga & K1 & K2 & K3 & K1 & K2 & K3 \\
\hline 1 & Suami & 30 & 28 & 30 & 100 & 93,33 & 100 \\
2 & Istri & - & 2 & - & - & 6,67 & - \\
\hline & Jumlah & 30 & 30 & 30 & 100 & 100 & 100 \\
\hline
\end{tabular}

Keterangan :

K1 : Pembelian Bibit

K2 : Penjuakan Ternak

K3 : Pembelian Terak

Tabel 6, menjelaskan bahwa aspek pengambilan keputusan peternak dalam kegiatan pembelian bibit (K1), penjualan ternak (K2) dan pembelian ternak (K3) yang lebih berperan didominasi oleh suami. Namun pada kegiatan penjualan ternak (K2) istri juga terlibat oleh. Hal ini sesuai dengan pendapat Sofiana (2018), bahwa keputusan dalam menjual atau membeli ternak serta dalam pemanfaatan uang hasil penjualan ternak kurang melibatkan wanita dalam menyumbang pemikiran dalam pengambilan keputusan.

\section{Peran tenaga kerja keluarga terhadap aspek manfaat}

Berdasarkan penelitian yang dilaksanakan di Kelurahan Makalonsow Kecamatan Tondano Timur, aspek manfaat pada usaha sapi potong yang diperoleh peternak secara keseluruhan dapat yaitu dari segikebutuhan sehari-hari maupun dari segi kebutuhan pendidikan anak. Manfaat dari kebutuhan sehari-hari yakni dapat memenuhi kebutuhan seperti sandang dan pangan. Hal ini sesuai pendapat Puspitawati (2012), bahwa peran tenaga kerja terhadap aspek manfaat diartikan sebagai semua aktivitas keluarga harus mempunyai manfaat yang sama bagi seluruh anggota keluarga.

\section{KESIMPULAN}

Berdasarkan hasil penelitian, menunjukan kepala keluarga berperan penting, terhadap usaha pemeliharaan ternak sapi potong di Kelurahan Makalonsow Kecamatan Tondano Timur.

\section{DAFTAR PUSTAKA}

Ananta. A, H. Hafid dan L.O.A. Sani, 2015. Faktor-faktor yang mempengaruhi produktivitas usaha ternak sapi bali pada peternak transmigran dan nontransmigran di Pulau Kabaena Kabupaten Bombana. JITRO, 2(3):52-67.

Badan Pusat Statistik Kabupaten Minahasa, 2019.

Darmawi. D. 2012. Peranan tenaga kerja anggota keluarga dalam usaha pemeliharaan sapi di Kabupaten 
Tanjung Jabung Barat. Jurnal Ilmiah Ilmu-Ilmu Peternakan, 15(2):48-58.

Nurdiyansah. I, D. Suherman dan H.D. Purwanto. 2020 Hubungan karakteristik peternak dengan skala kepemilikan sapi perah di Kecamatan Kabawetan Kabupaten kepahiang. Buletin Peternakan Tropis, 1(2):64-72.

Paturochman. M. 2012. Penentuan Jumlah dan Teknik Pengambilan Sampel. Unpad Press, Bandung, 55-56.

Purtanto. R, 2016. Analisis keuntungan peternak sistem gaduhan di Desa Pogalan Kecamatan Pakis Kabupaten Magelang, Ecces. 3(2):1-31.

Puspitawati, H. 2012. Gender dan Keluarga: Konsep Dan Realita Di Indonesia. PT IPB Press. Bogor.

Rintjap. A.K, B.F.J. Sondakh, F.S.F. Oley dan A.A. Sajow. 2018. Peran penyuluhan terhadap pengambilan keputusan dalam penerapan teknologi inseminasi buatan ternak sapi potong, Semnas Persepsi III Manado: 213-218. 6 September 2018.

Sari. A.I, S.H. Purnomo dan E.T. Rahayu. 2010. Sistem pembagian kerja, akses dan kontrol terhadap sumber daya ekonomi dalam keluarga peternak rakyat sapi potong di Kabupaten Grobogan. Jurnal Sains Peternakan, 7(1):36-44.

Siregar, S. 2011. Stastika Deskriptif Untuk Penelitian. Edisi Kedua. PT. Raja Grafindo. Jakarta.

Sofiana. J, 2018. Tingkat partisipasi perempuan dalam usaha pemeliharaan ternak sapi potong di sentra peternakan rakyat (SPR) Ridho Ilahi Kecamatan Wanasaba Kabupaten Lombok Timur. Tesis Universitas Mataram.

Solikhah. A. 2016. Statistik deskriptif dalam penelitian kualitatif, Komunika. 10(2):342-362.
Susanti H. 2015. Hubungan Antara Curahan Waktu Kerja Keluarga Dan Pendapatan Pada Usaha Peternak Sapi Potong Di Desa Samangki Kecamatan Simbang Kabupaten Maros, Skripsi.Fakultas Peternakan Universitas Hasanuddin Makassar.

Tumober, 2014. Analisis keuntungan pemeliharaan ternak sapi Kecamatan Suluun Tareran Kabupaten Minahasa Selatan. Zootek, 34(2):18-26.

Utari D. 2017. Pengalokasian waktu kerja keluarga dalam usaha ternak dan dampaknya terhadap pedapatan rumah tangga. Prosiding seminar nasional teknologi peternakan dan veteriner. Balai Besar Pengkajian dan Pengembangan Teknologi Pertanian Bogor, 8-10 Agustus 2017. 